\title{
USABILITY STUDY OF SELF-SERVICE SYSTEM IN GADJAH MADA UNIVERSITY LIBRARY
}

\author{
KUSRINIARTI Dwi Lestariningsih ${ }^{1, a}$, RIANTI Indah Lestari, ${ }^{1, b}$, \\ RIRI Nasirly ${ }^{1, c}$, MAIRA Himadani ${ }^{1, \mathrm{~d}}$, RINI Dharmastiti $^{1, \mathrm{e}}$ \\ ${ }^{1}$ Departement of Mechanical and Industrial Engineering, \\ Engineering Faculty, University of Gadjah Mada, \\ Jl. Grafika no.2, Yogyakarta, Indonesia \\ ak.dwilestari@gmail.com, ${ }^{b}$ riyanti_indah@yahoo.com, ${ }^{\mathrm{C}}$ rie_ti37@ymail.com, \\ ma1ra_indeegirl@yahoo.co.id, 'erini@ugm.ac.id
}

Keywords: usability, self-service system, Standard Operating Procedure, independent t-test

\begin{abstract}
Changing system from conventional to self-service system brings many advantages for a better service. In other hand, this transition force people to adapt with the new system. This research aimed to identify usability of self-service system in library, particularly in the Standard Operating Procedure (SOP) on loans process. The methods of this research consist of user tasking, questionnaires, and open ended interviews. Usability testing conducted based on usability attributes including effectiveness, efficiency, and satisfaction. After obtaining the test result from the data, the statistical tests related data attributes are analyzed using independent t-test. The results of this study showed a significant difference between the initial conditions and the improved condition. The improved loans procedures give better result than the existing one.
\end{abstract}

\section{Introduction}

Computer-based system has been widely applied on many services. One of its applications is integrated computer with barcode scanner. This barcode system then allows people to turn the conventional service system to self-service system. The application of self-service system is generally found on the supermarket, food service, department store, or book store (Cho et al, 2010).

The implementation of new service system indeed provides many advantages. Therefore, system transition becomes a necessary investment. There are some advantages of self-service system such as reducing waiting time, self-check ability, reducing queues and reducing workers (Cho et al, 2010).

Furthermore, the use of self-service system also has been used for educational institutions. This application is used by Universitas Gadjah Mada for library activity. The working principle of the system is not much different from the system at the supermarket. The computer system is integrated with a barcode scanner to read the ID code and the book code. Thus, the loans process which originally performed by operator, can be done by the students.

The new system requires a learning process to enable user executing the procedure as expected. The learning process usually takes time, especially when dealing with variety users. The less time spent by a user to understand the system, the more system can be said usable. It is inferred based on the usability concept proposed by Nielsen (1993) where learnability is one of the aspects.

The existence of the new loans system is certainly expected to provide better service performance and efficient in the provision of employee. However, the application of new technology in a system does not necessarily have a significant impact directly. Based on our case study in the central library of the Universitas Gadjah Mada, many users do not easily understand the system of loans books.

Actually, the process of the system has been equipped with the Standard Operation Procedure (SOP) on the computer side. SOP contains every step in service system. The objective of the SOP is to help user to use the service in a proper way. SOP is a part of ergonomic aspect in designing system because it will affect the effectiveness, efficiency, and satisfaction for the user. 
However, not all students could do the loans process smoothly. Novice users generally take longer time to do the process. Sometimes, the users still ask the operator for help. It caused a queuing and created an inefficient process.

The existence of the problems in the system motivates some researchers to conduct research related to system usability. Brophy (1996) conducted a study on the applicability of the self-service system in the library. This study aims to identify the issues arising from the implementation of selfservice systems. In other areas, Bodendrof and Saueressig (2000) conducted a study related to the self-service system to built more efficient system on public administration and improve customer service. Then, ORACLE (2009) has been researching on the success of self-service system for improved customer service.

Issues related to self-service system cannot be separated from the SOP issues that affect the fluency of the system process. Knaup et al. (2008) has conducted research in health areas that associated with implementing usability of SOP on Coordination Centre of Clinical Test in Germany. In addition, Hassan et al. (2011) evaluated the concept of reusability in academic management system that is applied to the University in Malaysia. However, there are no studies that appropriate to the loans system in library.

Based on the background above, we conduct a usability assessment of loans system focusing on the implementation of the SOP at library of Universitas Gadjah Mada. The result of this research is expected to improve the existing system and support the better loans system.

\section{Method}

This research is conducted by giving task to the participant then followed by questionnaire and open ended interview. There were twelve participants that divided into two groups for different tasking condition (Rubin and Chisnell, 2008). This amount follows Nielsen's rule (1993). Tasking I for existing condition, and tasking II made after the system procedure improved.

Once the tasking data and questionnaire obtained, it tested based on statistical attributes and then analyzed by independent test. The results of statistical analysis then interpreted to obtain a recommendation that can be used as an improvement over research object.

The design of tasks and questionnaires are made based on the attributes of usability; effectiveness, efficiency, and satisfaction. Each attribute is measured by several parameters shown in Table 1 and the task being investigated is shown in Table 2.

The statistical testing began with a hypothesis:

H0: There is no difference between data before and after using the flowchart loans procedures

H1: There is difference of the data before and after using the flowchart loans procedures

Furthermore, the data from questionnaires and interviews were analyzed using percentages. This data is used to support the results obtained from the tasking data.

\section{Result and Discussion}

Tasking result. On the implementation of tasking I, there were six respondents practicing loans process in library. All respondents perform loans procedures well. However, there were four respondents who made a mistake along the process. Furthermore, three respondents were also asked the operator to help the loans process as described in Table 3. 
Tabel 1. Usability Attributes and Testing Parameters

\begin{tabular}{|c|c|c|}
\hline No. & $\begin{array}{l}\text { Usability } \\
\text { Attribute }\end{array}$ & Parameter \\
\hline 1 & Effectiveness & Percent of finished task \\
\hline \multirow[t]{3}{*}{2} & \multirow[t]{3}{*}{ Efficiency } & Time to finish the task \\
\hline & & Percent of error \\
\hline & & $\begin{array}{l}\text { Amount of respondent who } \\
\text { need operator for help. }\end{array}$ \\
\hline \multirow[t]{2}{*}{3} & \multirow[t]{2}{*}{ Satisfaction } & Score of SOP advantages \\
\hline & & Stress level \\
\hline
\end{tabular}

Tabel 2. Task procedure

\begin{tabular}{|l|l|}
\hline No. & \multicolumn{1}{|c|}{ Loan process } \\
\hline 1 & Entering loan desk \\
\hline 2 & Scan ID card \\
\hline 3 & Scan book barcode \\
\hline 4 & Print struck \\
\hline 4 & Stamp date \\
\hline
\end{tabular}

Tabel 3. Tasking Result

\begin{tabular}{|l|l|l|}
\hline & Tasking I & Tasking II \\
\hline $\begin{array}{l}\text { Average task } \\
\text { done }\end{array}$ & $86,67 \%$ & $100 \%$ \\
\hline $\begin{array}{l}\text { Average } \\
\text { operator } \\
\text { assistance }\end{array}$ & $50 \%$ & $16,67 \%$ \\
\hline $\begin{array}{l}\text { Average } \\
\text { processing } \\
\text { time }\end{array}$ & $76,17 \mathrm{~s}$ & $63 \mathrm{~s}$ \\
\hline
\end{tabular}

The average task performed by the respondents of tasking I is $86.67 \%$. This is influenced by the mistakes made by three respondents. On the other hand, the average demand of operator assistance is $50 \%$.

On the implementation of tasking II, the condition of loans system is distinguished by providing improvements to the SOP by a better flowchart. In this second tasking, all respondents completed the entire procedure very well and only one respondent who asked operator for help. The average task performed by the respondents of tasking II is $100 \%$. There is no mistake on the process. On the other hand, the average of operator assistance required by the respondents is $16.67 \%$. Based on these results, it can be seen that the tasking in the improved condition respondents gave a better performance. 
Based on recapitulation of process time from tasking I and II, there are differences in the average processing time in both data. Average time on the tasking process I is 76,17 seconds, while the average processing time on a tasking II is 63 seconds. These results indicate that the data tasking II gives the average processing time less than tasking I.

Statistical test. The result of independent t-test of the data describes on Table 4 . In the whole process, the t-test showed that the average time on the tasking process I differ significantly from the average time tasking process II at $85 \%$ confidence level. However, if the time broke down into each procedure, some processes show significant differences while some others do not.

Based on Table 4, the entering process time required on tasking I significantly different from the time of entry tasking II. This suggests that the search process provides more rapid loans process. Similar results also occurred on the date stamp. In tasking I, there are three respondents did not stamp the date, while the data tasking II all respondents did it. Thus, improved flowchart provides increased user awareness in implementing loans procedures.

Furthermore, time to scan the ID card, barcode scanning books, and print receipts showed no significant differences. Based on the observations, scanning ID and printing struck process does not take long time. While in the process of scanning the book barcode, the time taken by the respondent did not differ significantly because of barcode location problem. The books in library have a different location. Although respondents had learned the procedure to be performed, they still require considerable time to locate the barcode.

Tabel 4. Independent t-test result

\begin{tabular}{|l|c|c|l|l|}
\hline \multicolumn{1}{|c|}{ Parameter } & $\alpha$ & Significance (2-taled) & Decision & \multicolumn{1}{|c|}{ Conclusion } \\
\hline Overall process & 0.15 & 0.113 & Reject Ho & $\begin{array}{l}\text { Data significantly different at } \\
\text { level } 85 \%\end{array}$ \\
\hline $\begin{array}{l}\text { Entering loan } \\
\text { desk }\end{array}$ & 0.05 & 0.014 & Reject Ho & $\begin{array}{l}\text { Data significantly different at } \\
\text { confidence level 95\%. }\end{array}$ \\
\hline Scan ID card & 0.05 & 0.782 & $\begin{array}{l}\text { Cannot } \\
\text { Reject Ho }\end{array}$ & $\begin{array}{l}\text { Data are not significantly } \\
\text { different }\end{array}$ \\
\hline Scan Book & 0.05 & 0.951 & $\begin{array}{l}\text { Cannot } \\
\text { Reject Ho }\end{array}$ & $\begin{array}{l}\text { Data are not significantly } \\
\text { different }\end{array}$ \\
\hline Print Struck & 0.05 & 0.761 & $\begin{array}{l}\text { Cannot } \\
\text { Reject Ho }\end{array}$ & $\begin{array}{l}\text { Data are not significantly } \\
\text { different }\end{array}$ \\
\hline $\begin{array}{l}\text { Stamp return } \\
\text { date }\end{array}$ & 0.05 & 0.000 & Reject Ho & $\begin{array}{l}\text { Data significantly different at } \\
\text { level 95\%. }\end{array}$ \\
\hline $\begin{array}{l}\text { Operator } \\
\text { assistance }\end{array}$ & 0.1 & 0.073 & Reject Ho & $\begin{array}{l}\text { Data significantly different at } \\
\text { level 90\%. }\end{array}$ \\
\hline
\end{tabular}


Tabel 5. Result Summary

\begin{tabular}{|l|l|l|l|l|l|}
\hline \multirow{2}{*}{ No. } & $\begin{array}{c}\text { Usability } \\
\text { attribute }\end{array}$ & \multicolumn{1}{|c|}{ Parameter } & Tasking I & Tasking II & \multicolumn{1}{|c|}{ Result } \\
\hline 1 & Effectiveness & $\%$ of finished task & $86,67 \%$ & $100 \%$ & Increase \\
\hline \multirow{2}{*}{2} & \multirow{2}{*}{ Efficiency } & Time to finish the task & 76,17 & 63 & $\begin{array}{l}\text { Decrease and } \\
\text { significantly } \\
\text { different }\end{array}$ \\
\cline { 3 - 6 } & & $\%$ of error & $13,33 \%$ & $0 \%$ & $\begin{array}{l}\text { Decrease and } \\
\text { significantly } \\
\text { different }\end{array}$ \\
\cline { 3 - 6 } & & $\%$ of operator assistance & $50 \%$ & $16,67 \%$ & $\begin{array}{l}\text { Decrease and } \\
\text { significantly } \\
\text { different }\end{array}$ \\
\hline 3 & Satisfaction & Advantage of SOP & $40 \%$ & $66,6 \%$ & Increase \\
\hline & & Stress & $46 \%$ & $40 \%$ & Decrease \\
\hline
\end{tabular}

In the parameter of operator assistance, there are significant differences between before and after improvements the SOP. It indicates that the new flowchart helps users to be more independent in carrying out the process of loans.

Flowchart benefit and error process obtained from questionnaires. Respondents of the tasking I gave an average score of 2.0 on flowchart benefits (scale 5), while respondents in the tasking II gave score 3.3. This shows that the improved flowchart provides more benefits to the user.

At error point, there is a decreasing procedural error. Error score of respondents in tasking I is 3.0, while the scores of the respondents tasking II error is 2.3. This shows that respondents in the tasking I do more procedural errors than respondents in tasking II. The results are consistent with the tasking respondent committed procedural error where respondents declined after the given flowchart.

Scores of stress level during the loans process using a computer also gives an improvement. This indicates that the flowchart helps users to improve satisfaction. Smaller stress levels support the decrease of average time taken by respondents to complete the task.

Nonprocedural problems. In addition to the problems related procedure, there are some non procedural issues that affect loan processing time.

\section{Location of barcode}

The first biggest problem complained of by $58 \%$ of respondents is the barcode location. Respondents need to flip through the book to find the location of the barcode. This led to a process of scanning the barcode did not differ significantly on tasking I and II.

\section{Barcode scanner}

The next nonprocedural problem is the barcode scanner. $42 \%$ of the respondents complained that the scanner is less sensitive when used.

Based on the description of data acquisition and processing are performed, analyzing the results of the usability variables referenced in this study are given in Table 4.

Based on the value of each attribute, there is an improvement of each parameter. Thus, it can be concluded that there is an improvement on the instructions procedure provides improved usability attributes. 


\section{Conclusion}

Based on the results and discussion that has been done, it can be concluded as follows:

1. There are some usability problems in Library of Universitas Gadjah Mada related to implementation procedures. Problems include loan processing time, error rate, aid workers, the level of stress, and satisfaction with the benefits of the procedure.

2. There is a better usability system at the Library of Universitas Gadjah Mada after SOP improvement in flowchart. This improvement is shown by the increase in loan processing time, error rate, aid workers, level of stress, and satisfaction with the benefits of the new procedure.

\section{Reference}

[1] Bosert, J.L, 1991, Quality Functional Deployment: A Practitioner's Approach. ASQC Quaility Press, New York.

[2] Cho, H. and Fiorito, S.S., 2010, Self-Service Technology in Retailing, Emerging Issues in Management, 43-55.

[3] Development Core Team, 2008, A language and environment for statistical computing. $R$ Foundation for Statistical Computing, Vienna, Austria. [online accessed on 13 January 2013] URL: http://www.R-project.org

[4] Dumas, J. S. and Janice C. R., 1993, A practical guide to usability testing. Norwood, N.J.: Ablex. International Organization for Standardization.

[5] Axup, J and Stephen V., 2005, Formative Research Methods For The Extremely Mobile: Supporting Community, University of Queensland, Australia.

[6] Karat, J., \& Karat, C. M., 2003, The evolution of user-centered focus in the human-computer interaction field. IBM Systems Journal Archive, 42, 532-541.

[7] Landauer, T. K., 1995, The trouble with computers: Usefulness, usability and productivity, Cambridge, Mass MIT Pr.

[8] Lazar, J. and Preece, 2002, "Social Considerations in Online Communities: Usability, Sociability and Success Factors" in H. van Oostendorp (ed.) Cognition in the Digital World. NJ: Lawrence Erlbaum Associates Inc.

[9] Lederer and Prassad, A. L. P. J., 1992, Nine Management Guidelines for Better cost Estimating. Communications of the ACM, 35(2), 51-59.

[10] Nielsen, J., 1993, Usability Engineering. Boston: Academic Press.

[11] Preece, J., 1994, Human-Computer Interaction, Addison-Wesle.

[12] Pressman, R. S., 1992, Software engineering: A practitioner's approach. New York: McGraw Hill.

[13] Ridwan., 2003, Skala Pengukuran Variabel-variabel Penelitian, Bandung: Alfabeta.

[14] Rubin, J and Chisnell D., 2008, Handbook of Usability Testing, Canada: Wiley.

[15] Sugiyono, 2005, Statistik Untuk Penelitian. Bandung: Alfabeta.

[16] Shackel, B., 1990, Human factors and usability. In J. Preece and L. Keller (eds.), HumanComputer Interaction: Selected Readings. London: Prentice Hall, 27-41. 